Ophthalmologica 1959;137:193

\title{
Demonstration der neuen Haag-Streit Spaltlampe 900
} Th.

Schmidt

Bern

(Erscheint demnächst ausführlich in Ophthalmologica.) 